\title{
PERBAIKAN JOINT KOLOM BALOK DENGAN FEROSEMEN YANG DIBEBANI SIKLIK SESUAI DENGAN PBI 1971
}

\author{
Muhammad Faiz Irsyad ${ }^{1}$ M. Zardan Araby ${ }^{2}$ Mahlil $^{3}$ \\ 1Mahasiswa, Jurusan Teknik Sipil, Universitas Syiah Kuala, Banda Aceh 23111, Indonesia \\ 2,3Dosen, jurusan Teknik Sipil, Universitas Syiah Kuala, Banda Aceh 23111, Indonesia. \\ Email: irsyadfaiz1@gmail.com
}

\begin{abstract}
The area of the beam-column joint is a critical in resisting of an earthquake, because there is a large shear moment in the joint which can cause damage and collapse. Therefore, it is necessary to improve the structure with an appropriate method. One improvement alternative that can be used is by applying ferrocement material. This study aims to see the behavior joint of the PBI 1971 column beam due to cyclic loads after repair with ferrocement material. The object of this research is to study the beam-column joint based on PBI 1971 standard where the joint does not have shear reinforcement, so that structural repair efforts are needed. This study used a beam-column joint specimen with a beam size of $30 \times 40 \times 120 \mathrm{~cm}$ and a column size of $30 \times 30 \times 200 \mathrm{~cm}$. Repair is done by attaching the ferrocement to the area joint. The test is carried out by compressive cyclic loading and tension lateral to the beam. Based on the results of research, the addition of ferrocement in the beam-column joint area of the PBI 1971, the maximum compressive load was 7,86 tf and the maximum tensile load was 7,37 tf and the ductility factor was 10,83.
\end{abstract}

Keywords: Beam column joint, Ferrocement, Cyclic Load, Retrofitting, PBI 1971

\begin{abstract}
Abstrak
Daerah joint balok dan kolom merupakan bagian yang kritis dalam menahan gempa, karena terjadi momen geser yang besar pada bagian joint yang dapat menimbulkan kerusakan dan keruntuhan sebuah struktur bangunan. Oleh karena itu, perlu upaya perbaikan struktur dengan metode yang sesuai. Salah satu alternatif perbaikan yang dapat digunakan yaitu dengan mengaplikasikan bahan ferosemen. Penelitian ini bertujuan untuk melihat perilaku joint balok kolom berdasarkan PBI 1971 akibat beban siklik setelah perbaikan dengan bahan ferosemen. Objek penelitian merupakan joint balok kolom standar PBI 1971 di mana pada bagian joint tidak menggunakan tulangan geser, sehingga diperlukan upaya perbaikan struktur. Penelitian ini menggunakan benda uji berbentuk joint balok kolom dengan ukuran balok $30 \times 40 \times 120 \mathrm{~cm}$ dan ukuran kolom $30 \times 30 \times 200 \mathrm{~cm}$. Perbaikan dilakukan dengan melekatkan ferosemen pada daerah joint. Pengujian dilakukan dengan pembebanan siklik secara tekan dan tarik dengan arah lateral terhadap balok. Berdasarkan hasil penelitian penambahan ferosemen pada daerah joint balok kolom PBI 1971 didapatkan beban tekan maksimum sebesar 7,86 tf dan beban tarik maksimum sebesar 7,37 tf dan faktor daktilitas didapat sebesar 10,83.
\end{abstract}

Kata kunci: Joint balok-kolom, ferosemen, beban siklik, perbaikan struktur, PBI 1971.

\section{Pendahuluan}

Indonesia merupakan negara yang terletak pada pertemuan tiga lempeng utama bumi, yaitu lempeng Eurasia, lempeng Indo-Australia dan lempeng Pasifik. Oleh karena itu, daerah-daerah di Indonesia pada umumnya rawan terhadap gempa. Menurut data histori kegempaan BMKG [1], angka rata-rata kegempaan di Indonesia mencapai angka 4.500 kali per tahun. Untuk gempa berkekuatan di atas $5 \mathrm{SR}$, tercatat angka rata-rata 365 kali per tahun atau satu gempa per hari.

Dalam beberapa kejadian gempa di Indonesia, banyak bangunan yang terbuat dari struktur beton bertulang yang mengalami kerusakan dan bahkan mengalami keruntuhan. Salah satu kerusakan struktur yang sering terjadi berada pada pertemuan balok dan kolom (beam-column joint). Daerah joint balok kolom merupakan daerah kritis pada suatu struktur beton bertulang yang menerima beban dari kolom di atasnya dan beban balok yang berada di sekitarnya. Pada saat terjadi gempa, joint balok kolom akan mengalami gaya geser horizontal dan vertikal yang besar dan dapat menimbulkan keruntuhan geser yang bersifat getas.

Berdasarkan PBI (Peraturan Beton Indonesia) 1971 [2] salah satu metode perencanaan desainnya adalah dengan menggunakan metode perencanaan beban kerja. Perencanaan tersebut akan menghasilkan beton bertulang dengan kondisi yang diharapkan yaitu lendutan yang terjadi masih dalam batas yang diijinkan dan retakan yang timbul masih dapat dikendalikan

Kapasitas kekuatan pada daerah joint balok kolom beton bertulang dapat diperbesar dengan penambahan tulangan sengkang di daerah joint dan penyaluran tulangan dari balok ke kolom. Kurniadi [3] mengatakan bahwa bangunan yang menggunakan standar PBI 1971 tidak memenuhi persyaratan SCWB (Strong Column, Weak Beam) serta tidak memiliki kapasitas kolom yang cukup berdasarkan pembebanan yang berlaku saat ini. Prinsip rekomendasi perkuatan kemudian disusun untuk 
meningkatkan kapasitas struktur kolom agar dapat memenuhi

persyaratan standar perancangan yang berlaku. Oleh karena itu, objek penelitian ini adalah bangunanbangunan terdahulu yang masih menggunakan standar PBI 1971 di mana struktur bangunan pada daerah joint balok kolom tidak diberikan tulangan sengkang (tulangan geser). Hal ini dapat memperbesar kemungkinan kerusakan akan terjadi pada joint balok kolom bangunan yang masih menggunakan standar PBI 1971. Berdasarkan pertimbangan terhadap kerusakan tersebut, maka perlu upaya perbaikan struktur pada daerah joint balok kolom sebelum bangunan mengalami keruntuhan struktur dengan menggunakan metode perbaikan yang tepat dan mudah dilakukan di lapangan.

Seiring dengan berkembangnya ilmu tentang beton bertulang terdapat beton bertulang tipis yang berbeda dari beton bertulang biasa atau beton pratekan baik dari bahan hingga cara pemasangan tulangannya, yaitu ferosemen. Salah satu cara untuk meningkatkan kekuatan dan daktilitas pada struktur bangunan adalah me-retrofit joint tersebut dengan cara membungkus joint menggunakan ferosemen. Ferosemen terbuat dari mortar yaitu campuran antara pasir, semen dan air dengan perbandingan tertentu yang diberi beberapa lapisan kawat jala (wire mesh) sebagai pengikat dengan diameter kawat yang relatif kecil.

Tujuan dari penelitian ini adalah memberikan informasi mengenai kemungkinan hasil penelitian yaitu perilaku dan kekuatan joint balok kolom setelah penggunaan ferosemen sebagai salah satu alternatif perbaikan terhadap joint balok kolom tersebut.

Batasan dalam penelitian ini adalah Penelitian ini dilakukan di Laboratorium Kontruksi dan Bahan Bangunan Jurusan Teknik Sipil Fakultas Teknik Universitas Syiah Kuala. Benda uji yang direncanakan berbentuk joint balok kolom yang berbentuk huruf "T" dengan penampang segi empat dengan dimensi balok berukuran $30 \times 40 \times 120 \mathrm{~cm}$ dan kolom berukuran $30 \times 30 \times 200 \mathrm{~cm}$. Penelitian ini menggunakan benda uji yang merupakan replika dari bentuk sambungan (joint) balok kolom yang umum dapat ditemukan pada bangunan di berbagai wilayah Indonesia yang masih menggunakan standar PBI 1971 dengan asumsi perbaikan dilakukan sebelum joint mengalami keruntuhan dan pengujian dengan beban siklik dilakukan 28 hari setelah benda uji diperbaiki dengan pelekatan ferosemen pada area joint. Untuk kontrol mutu beton digunakan silinder beton dengan ukuran $15 \times 30 \mathrm{~cm}$ sebanyak 6 buah sedangkan untuk kontrol mutu ferosemen digunakan silinder beton dengan ukuran $10 \times 20 \mathrm{~cm}$ sebanyak 3 buah.

\section{Tinjauan Kepustakaan}

Pada bab ini berisi tentang teori-teori dan konsep dasar yang sesuai dengan penelitian ini yang dikutip dari hasil penelitian terdahulu dan para ahli serta dari referensi-referensi yang ada.

\subsection{Beton Bertulang}

Beton bertulang adalah suatu bahan material yang terbuat dari campuran beberapa material seperti agregat kasar, agregat halus, air, dan semen yang diperkuat dengan baja tulangan dengan jumlah dan luas tertentu. Kombinasi dari beton dengan baja tulangan tersebut menghasilkan bahan bangunan yang mempunyai sifat-sifat yang baik dari masing-masing bahan bangunan tersebut .

\subsection{Kuat Tekan}

Mulyono [4] menyatakan kuat tekan adalah kemampuan beton untuk menerima gaya tekan persatuan luas. Kuat tekan merupakan sifat utama yang umumnya harus dimiliki oleh beton, karena itu beton yang tidak memiliki kekuatan yang sesuai dengan kebutuhan maka beton tersebut menjadi tidak berguna. Beberapa faktor yang sangat mempengaruhi kekuatan beton adalah faktor air semen dan kepadatan, umur beton, jenis semen, jumlah semen, agregat dan cara pelaksanaan pembuatan beton. Nilai kuat tekan beton ditunjukkan dalam tegangan desak beton $\left(f^{\prime} c\right)$, dapat dihitung dengan persamaan berikut:

$$
\mathrm{f}^{\prime} \mathrm{c}=\frac{\mathrm{P}}{\mathrm{A}} .
$$

Di mana: $\mathrm{f}^{\prime} \mathrm{c}=$ kuat tekan beton $\left(\mathrm{N} / \mathrm{mm}^{2}\right)$;

$$
\begin{aligned}
& \mathrm{P}=\text { beban yang bekerja }(\mathrm{N}) \text {; dan } \\
& \mathrm{A}=\text { luas penampang benda uji }\left(\mathrm{mm}^{2}\right) .
\end{aligned}
$$

\subsection{Tegangan dan Regangan Baja}

Tegangan adalah gaya yang bekerja pada baja dalam setiap satuan luas penampang baja. Menurut Timoshenko [5] menyatakan untuk menghitung tegangan baja dapat menggunakan persamaan:

$$
f s=\frac{P}{A s}
$$

Di mana :

$f s \quad=$ Tegangan baja (MPa);

$P \quad=$ Beban $(\mathrm{N})$; dan

As $\quad=$ Luas penampang baja $\left(\mathrm{mm}^{2}\right)$.

regangan baja merupakan respon dari tegangan, regangan adalah perbandingan antara pertambahan panjang yang terjadi akibat tegangan dengan panjang baja awal. regangan baja dapat dihitung menggunakan persamaan:

$$
\varepsilon_{s}=\frac{\Delta l}{l_{0}}
$$

Di mana :

$\varepsilon_{s} \quad=$ Regangan baja;

$\Delta l \quad=$ Pertambahan panjang awal ( $\mathrm{mm})$; dan

$l_{0} \quad=$ Panjang awal $(\mathrm{mm})$. 


\subsection{Pertemuan Balok dan Kolom}

Pertemuan (joint) balok dan kolom perlu mendapat perhatian dalam hal perencanaan struktur. Karena pada pertemuan sambungan balok dan kolom terdapat konsentrasi tegangan yang tinggi akibat dari gaya gempa yang ada. Tegangan yang timbul akan menyebabkan perbedaan reaksi tegangan antara suatu sisi balok dengan sisi lainnya yaitu tegangan tarik dan tegangan tekan, antara tulangan atas balok dengan tulangan bawah balok masing-masing mengalami tegangan berkebalikan. Dengan memberikan perhitungan struktur yang cermat dan perhatian yang baik pada pertemuan balok dan kolom akan mengurangi resiko terbentuknya sendi plastis pada area tersebut yang dapat menyebabkan kehancuran Setiawan [6].

\subsection{Daktilitas}

Menurut SNI-1726-2002 [7], daktilitas adalah kemampuan struktur gedung untuk mengalami simpangan pasca-elastik yang besar secara berulang kali dan bolak-balik akibat beban gempa, sambil mempertahankan kekuatan dan kekakuan sehingga gedung tetap berdiri walaupun sudah berada dalam ambang keruntuhan struktur. Daktilitas beton dapat dilihat melalui kurva hubungan tegangan dan regangan, kurva yang memiliki penurunan kekuatan tekan yang cepat setelah melalui beban puncak menggambarkan struktur bangunan dengan daktilitas yang rendah, hal ini akan menyebabkan keruntuhan getas yang terjadi secara tiba-tiba.

\subsection{Beban Siklik}

Beban siklik atau cyclic load adalah pembebanan berulang atau bolak balik, seperti beban tekan dan tarik berulang yang teratur pada suatu bagian, yang dapat menyebabkan fraktur kelelahan (fatigue). Pada suatu struktur yang dibebani dengan beban siklik, energi yang terdisipasi selama pembebanan merupakan luas daerah dalam kurva hubungan beban dan displacement yang dihasilkan dalam satu siklus beban tekan dan beban tarik.

\subsection{Hysteretic Loop \& Hysteresis Energy}

Kurva hysteretic loop dihasilkan dari pengujian dengan pembebanan berulang (cyclic load) yang merupakan hubungan antara beban (load) dan simpangan (displacement).

\subsection{Energi Disipasi \& Energi Input Total}

Energi disipasi merupakan besar energi yang dapat diserap oleh struktur selama terjadi pembebanan melalui mekanisme kerusakan berupa keretakan struktur dan kelelehan tulangan. Energi total yang diberikan kepada struktur pada suatu pembebanan disebut energi input. Pada kurva histeritik, energi input diidentifikasi sebagai luas daerah yang dibatasi kurva tertutup histeresis beban dan perpindahan.

\subsection{Kekakuan}

Kekakuan dapat didefinisikan sebagai gaya yang diperlukan untuk memperoleh satu unit displacement. Nilai Kekakuan dapat ditulis dalam Persamaan berikut:

$$
\mathrm{k}=\frac{P_{1}+P_{2}}{\Delta_{1}+\Delta_{2}}
$$

\subsection{Ferosemen}

Definisi ferosemen menurut American Concrete Institute Committee 549 [8] adalah beton bertulang tipis yang dibentuk dari mortar semen hidrolis yang diberi beberapa lapisan kawat sebagai tulangan utama dengan diameter kawat yang relatif kecil.

\subsection{Perbaikan Struktur}

Triwiyono [9] menyatakan bahwa ada dua jenis perbaikan yaitu repairing dan strengthening. Istilah repairing diterapkan pada bangunan yang sudah mengalami kerusakan, di mana telah terjadinya penurunan kekuatan dan diperbaiki untuk mencapai kekuatan semula. Sedangkan strengthening diterapkan pada bangunan yang mungkin belum mengalami kerusakan dengan cara modifikasi struktur untuk menaikkan kekuatan.

\section{Metodologi Penelitian}

\subsection{Sumber Data}

Sumber data yang digunakan untuk mendukung pelaksanaan penelitian ini diperoleh hasil pengujian di laboratorium, hasil-hasil penelitian yang telah dilakukan, dan literatur lainnya. Data-data yang dikumpulkan selama pengujian dilakukan adalah data kuat tarik baja dan wire mesh, data kuat tekan beton, data pembebanan dari load cell, data displacement dari transducer, dan data regangan tulangan baja dari strain gauge.

\subsection{Perencanaan Bennda Uji Joint Balok Kolom}

Benda uji yang direncanakan adalah elemen balok dan kolom beton bertulang yang berbentuk huruf " $T$ " dengan desain mutu beton K-200. Mix design diperoleh dengan metode trial berdasarkan berat volume beton. Benda uji dibuat berdasarkan kebutuhan penelitian, yaitu benda uji untuk pengujian kapasitas beban siklik pada joint balok kolom beton bertulang. Benda uji yang direncanakan terdiri dari beton normal dan besi tulangan polos dengan diameter $14 \mathrm{~mm}$ sebagai tulangan utama dan besi tulangan polos diameter $10 \mathrm{~mm}$ sebagai tulangan sengkang. Pada penelitian ini untuk perencanaan beton normal akan mengunakan agregat normal seperti batu pecah (split), pasir, air dan semen. 
Untuk melakukan kontrol mutu beton dan mutu mortar ferosemen diperlukan pembuatan benda uji silinder untuk mendapatkan kuat tekan beton. Pada saat pembuatan benda uji BMN-FI dilakukan pembuatan benda uji silinder dengan ukuran $15 \times 30$ cm dengan jumlah 6 buah untuk diuji pada hari ke 28 dan pada hari pengujian siklik dilakukan. Untuk kontrol mutu mortar ferosemen perbaikan dibuat benda uji silinder dengan ukuran $10 \times 20 \mathrm{~cm}$ dengan jumlah 3 buah dan pengujian kuat tekan dilakukan pada saat umur perbaikan benda uji sudah mencapai 28 hari. Maksud dari jumlah silinder benda uji kuat tekan dibuat 3 buah dalam satu hari usia pengujian adalah untuk memudahkan angka koreksi dalam mendapatkan hasil kuat tekan yang sudah direncanakan. Detail benda uji joint balok kolom dapat dilihat pada Gambar 1.
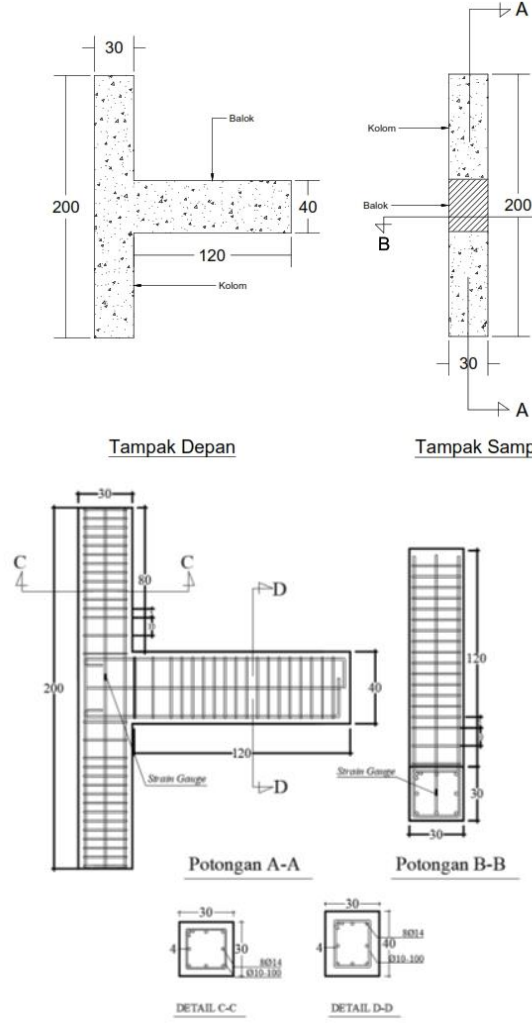

\section{Gambar 1. Bentuk Benda Uji dan Penulangan}

\subsection{Pekerjaan Persiapan}

Pekerjaan persiapan yang dilakukan adalah pengadaan material yang digunakan dalam pembuatan campuran adukan beton seperti pasir, split, semen, air, dan besi tulangan. Setelah itu, dilanjutkan dengan pemeriksaan material dan bahan yang digunakan dalam penelitian.

\subsection{Pengujian Kuat Tarik Baja Tulangan Beton}

Pada pengujian kuat tarik baja ini mutu baja ditentukan dengan uji tarik baja menurut prosedur SNI 2052-2017 [10], beban diberikan secara kontinyu sampai baja putus. Pembacaan regangan dilakukan setiap penambahan beban $200 \mathrm{~kg}$ melalui pembacaan transducer. Hasil pengujian ini digambarkan dalam suatu kurva hubungan tegangan tarik baja dengan regangan sehingga diperoleh kuat tarik baja dan regangan luluhnya.

\subsection{Pembuatan Benda Uji}

Benda uji dibuat dalam beberapa tahap mulai dari pembuatan cetakan, perakitan tulangan, pengecoran beton mutu normal, pemasangan wire mesh dan pengecoran mortar ferosemen. Detail pemasangan wire mesh dapat dilihat pada Gambar 2.

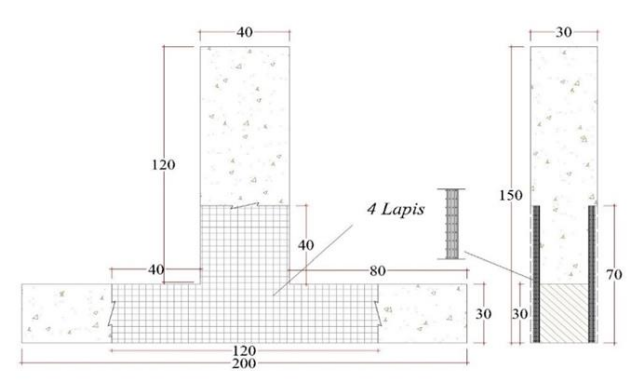

Gambar 2. Area Pemasangan wire mesh Perbaikan

\subsection{Pengujian dengan Beban Siklik}

Pengujian dilakukan setelah benda uji berumur 28 hari terhitung setelah hari pengecoran perbaikan dengan ferosemen. Kapasitas beban siklik yang diperhitungkan adalah kuat tekan beban yang dihasilkan dari pengujian kuat tekan benda uji silinder yang diuji pada hari yang sama. Benda uji joint balok kolom dipasang secara kaku pada rangka baja (loading frame) yang tersedia. Pada permukaan ujung bidang balok diletakkan plat baja sebagai landasan untuk load cell dalam memberikan beban yang diinginkan. Beban diberikan horizontal terhadap ujung balok. Beban horizontal diberikan oleh hydraulic jack yang terhubung dengan load cell yang dipasang ke benda uji. Pengujian dilakukan dengan cara dibebani beban siklik dengan control displacement akibat beban tekan dan beban dengan siklus displacement $0,75 \mathrm{~mm}, 1,5 \mathrm{~mm}, 3 \mathrm{~mm}, 6 \mathrm{~mm}$, $12 \mathrm{~mm}, 24 \mathrm{~mm}$ dan monotonik sehingga benda uji balok kolom hancur. Set up benda uji pada rangka baja (loading frame) saat dilakukan pengujian secara detail pada Gambar 3. 


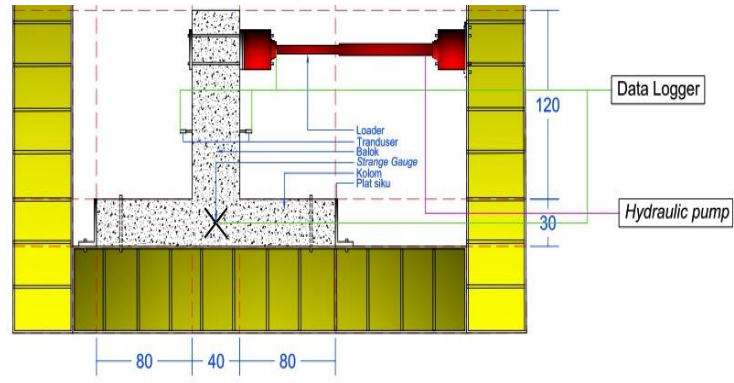

Gambar 3. Set Up Benda Uji pada Loading

Frame

\section{HASIL DAN PEMBAHASAN}

\subsection{Hasil Perencanaan Campuran Beton}

Perencanaan campuran (Mix design) untuk benda uji Jonit balok-kolom ini direncanakan berdasarkan ACI 211.1-91 [11]. Mutu beton rencana sebesar 21,05 MPa dengan faktor air semen (FAS) yang digunakan adalah 0,67 dan mutu ferosemen rencana sebesar 30 MPa dengan faktor air semen (FAS) yang digunakan adalah 0,5. Hasil komposisi campuran yang terdiri dari semen, air, pasir, dan agregat untuk $1 \mathrm{~m}^{3}$ beton dapat dilihat pada Tabel 1.

Tabel 1. Komposisi Campuran Beton per $\mathbf{m}^{3}$

\begin{tabular}{cccccc}
\hline Elemen & $\begin{array}{c}\text { FA } \\
\mathbf{S}\end{array}$ & $\begin{array}{c}\text { Semen } \\
(\mathbf{K g})\end{array}$ & $\begin{array}{c}\text { Air } \\
(\mathbf{K g})\end{array}$ & $\begin{array}{c}\text { Pasir } \\
(\mathbf{K g})\end{array}$ & $\begin{array}{c}\text { Split } \\
(\mathbf{K g})\end{array}$ \\
\hline Balok & 0,67 & 301,52 & 203 & 1015,4 & 830,84 \\
$\begin{array}{c}\text { Kolom } \\
\begin{array}{c}\text { Ferose } \\
\text { men }\end{array}\end{array}$ & 0,50 & 413,33 & 206 & 1182,6 & \\
\hline
\end{tabular}

\subsection{Hasil Pengujian Kuat Tekan Beton Silinder}

Pada saat pembuatan benda uji BMNFidibuatkan benda uji silinder untuk kontrol mutu dengan ukuran $15 \times 30 \mathrm{~cm}$ dengan jumlah 6 buah yang diuji bersamaan dengan hari pengujian siklik dilakukan. Untuk kontrol mutu mortar ferosemen juga dibuatkan benda uji silinder dengan ukuran $10 \times 20$ $\mathrm{cm}$ dengan jumlah 3 buah dan juga akan diuji bersamaan pada hari pengujian siklik dilakukan, adapun nilai kuat tekan beton tersebut disajikan pada Tabel 2.
Tabel 2. Hasil Uji Kuat Tekan Beton Silinder

\begin{tabular}{|c|c|c|c|c|c|}
\hline \multirow{2}{*}{ No. } & \multirow{2}{*}{$\begin{array}{c}\mathbf{f}^{\prime} \mathrm{c} \\
\left(\mathrm{kg} / \mathrm{cm}^{2}\right)\end{array}$} & \multirow{2}{*}{$(\mathrm{Xi}-\mathrm{X})^{2}$} & \multirow{2}{*}{ Sd } & \multicolumn{2}{|c|}{$f^{\prime} \mathrm{cr}$} \\
\hline & & & & $\left(\mathrm{kg} / \mathrm{cm}^{2}\right)$ & (MPa) \\
\hline S1 & 284,0 & 299,8 & \multirow{6}{*}{38,0} & \multirow{6}{*}{238,6} & \multirow{6}{*}{23,4} \\
\hline $\mathrm{S} 2$ & 262,1 & 1535,1 & & & \\
\hline S3 & 313,0 & 137,5 & & & \\
\hline S4 & 367,0 & 4322,8 & & & \\
\hline S5 & 272,1 & 850,2 & & & \\
\hline S6 & 309,5 & 66,9 & & & \\
\hline SF1 & 602,4 & 7849,7 & \multirow{3}{*}{89,7} & \multirow{3}{*}{365,9} & \multirow{3}{*}{35,9} \\
\hline SF2 & 423,1 & 8235,2 & & & \\
\hline SF3 & 516,0 & 4,6 & & & \\
\hline
\end{tabular}

\subsection{Hasil Pengujian Kuat Tarik Baja}

Nilai tegangan leleh $\left(\boldsymbol{f}_{\boldsymbol{y}}\right)$, tegangan ultimit $\left(\boldsymbol{f}_{\boldsymbol{u}}\right)$ dan regangan leleh $(\varepsilon)$ uji tarik beja tulangan yang telah dihitung dengan rumus (2.2) dan (2.3) dapat dilihat pada Tabel 3 berikut.

Tabel 3. Hasil Perhitungan Uji Tarik Baja Tulangan

\begin{tabular}{cccccc}
\hline \multirow{2}{*}{$\begin{array}{c}\text { Benda } \\
\text { Uji }\end{array}$} & \multicolumn{2}{c}{$\boldsymbol{f}_{\boldsymbol{u}}(\mathbf{M P a})$} & \multicolumn{2}{c}{$\boldsymbol{f}_{\boldsymbol{y}}(\mathbf{M P a})$} & \\
\cline { 2 - 5 } & Hasil & $\begin{array}{c}\text { Rata } \\
\text {-rata }\end{array}$ & Hasil & $\begin{array}{c}\text { Rata } \\
\text {-rata }\end{array}$ & $\boldsymbol{\epsilon}$ \\
\hline $14(1)$ & 554,2 & 544,6 & 382,2 & 372,6 & 0,32 \\
$14(2)$ & 535,0 & & 363,1 & & 0,22 \\
$10(1)$ & 544,3 & 543,1 & 374.5 & 374,9 & 0,30 \\
$10(2)$ & 541,8 & & 374,9 & & 0,03 \\
\hline
\end{tabular}

\subsection{Hasil Pengujian Beban Siklik}

\subsubsection{Pengujian Beban Siklik}

Beban maksimum yang dicapai oleh benda uji joint balok-kolom setelah pelekatan bahan ferosemen pada daerah joint adalah sebesar 7,86 tf beban tekan dan 7,37 tf beban tarik, beban tekan maksimum terjadi pada kontrol beban dengan displacement $12 \mathrm{~mm}$ siklus pertama dan beban maksimum tarik terjadi pada kontrol beban dengan displacement $12 \mathrm{~mm}$ siklus pertama.

\subsubsection{Beban dan Perpindahan Lateral}

Beban dan perpidahan lateral (displacement) yang dihasilkan dari pengujian siklik dapat dihubungkan dalam bentuk kurva antara beban dan displacement yang akan membetuk kurva hysteretic loop yang merupakan kurva gabungan antara setiap siklus pembebanan. Pada Gambar 4. 


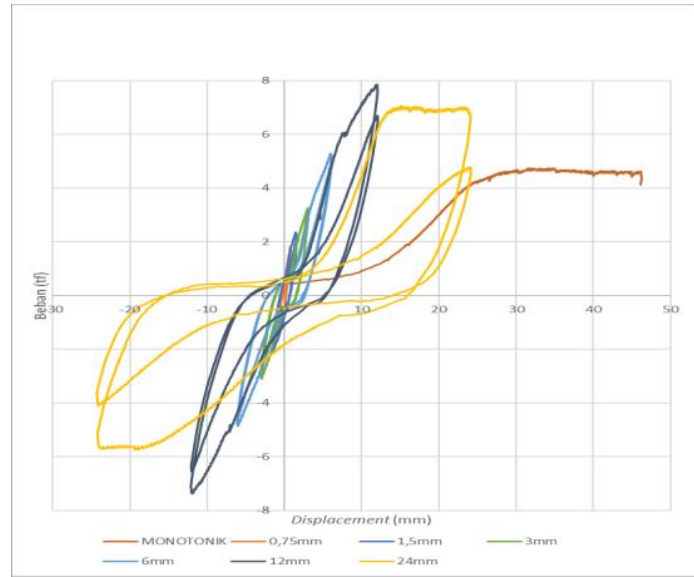

Gambar 4. Kurva Hysteretic Perilaku Struktur

\section{Terhadap Beban Siklik}

\subsection{Pola Retak}

Setelah selesai semua siklus pembebanan secara siklik dilakukan pembebanan monotonik terhadap benda uji untuk mendapatkan lendutan dan displacement maksimum benda uji, sehingga mengakibatkan terjadinya patahanan pada ujung balok yang bertemu kolom. Retakan tidak dapat dilihat lagi pada bagian joint. Displacement maksimum yang didapat pada saat pembebanan monotonik yaitu sebesar $45 \mathrm{~mm}$ dengan beban tekan sebesar 4,60 tf. Berikut pola gambar pola retak pada Gambar 5.

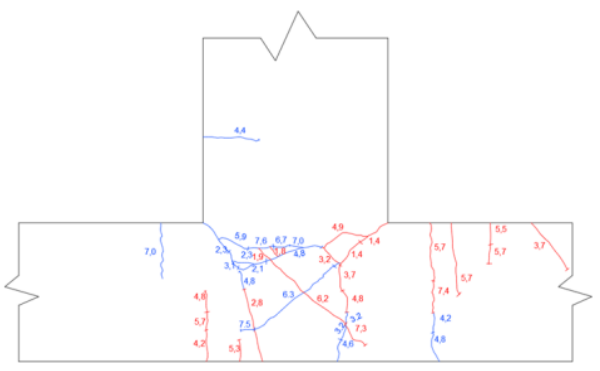

Gambar 5. Pola Retak Monotonik

\subsection{Pembahasan}

\subsubsection{Kekakuan}

Berdasarkan data hasil pengujian dan perhitungan (2.4), benda uji sebelum dilakukan perbaikan (BMNF) mengalami penurunan kekakuan dimulai dari perpindahan lateral $1,74 \mathrm{~mm}$ sampai pada perpindahan 24,04 $\mathrm{mm}$ sebesar 0,357 $\mathrm{mm}$. Benda uji setelah dilakukan perbaikan (BMN-FI) penurunan kekakuan dimulai dari perpindahan lateral $0,86 \mathrm{~mm}$ sampai dengan perpindahan lateral 24,075 $\mathrm{mm}$ dengan penurunan sebesar 0,109. Dari data tersebut dapat dismpulkan bahwa adanya penurunan presentase penurunan kekakuan sebesar $69,47 \%$ berikut grafiknya pada Gambar 6.

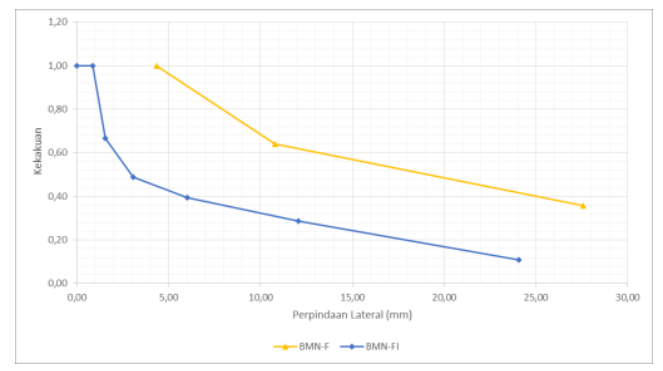

Gambar 6. Grafik Perbandingan Kekakuan

\subsubsection{Energi Desipasi dan Energi Input Total}

Berikut merupakan perbandingan Energi Desipasi dan Energi Input Total sebelum dilakukan perbaikan (BMN-F) dan sesudah diperbaiki (BMN-FI) Gambar 7. Grafik Perbandingan Energi Tekan dan Gambar 8. Grafik Perbandingan Energi Tarik

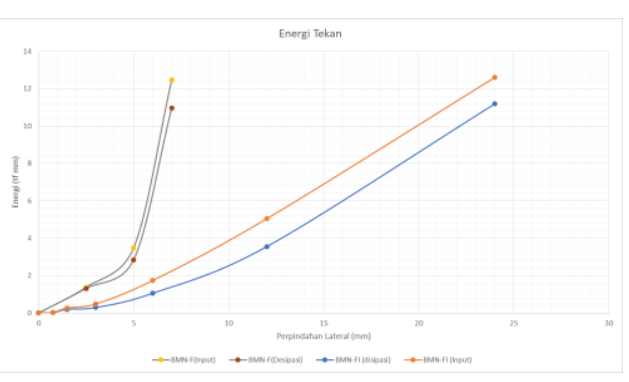

Gambar 7. Grafik Perbandingan Energi Tekan

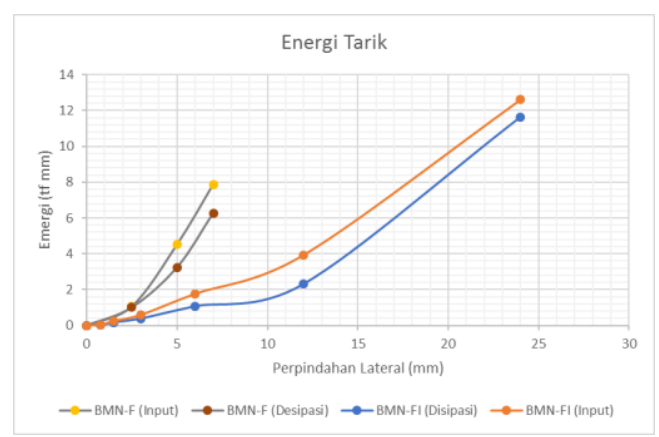

Gambar 8. Grafik Perbandingan Energi Tarik 


\subsubsection{Daktilitas}

Dari hasil pengujian benda uji sebelum diperbaiki (BMN-F) memiliki perpindahan ultimit $(\mu \mathrm{u})$ didapatkan sebesar 26,04 mm. Nilai perpindahan leleh ( $\mu \mathrm{y})$ sebesar $12,07 \mathrm{~mm}$, dan memiliki nilai daktilitas sebesar 2,16. Hasil pengujian dari benda uji yang sudah dilakukan perbaikan (BMN-FI) memiliki hasil perbandingan displacement maksimum $(\mu \mathrm{u})$ didapatkan sebesar $46,15 \mathrm{~mm}$ dengan displacement pada saat terjadi leleh ( $\mu \mathrm{y})$ sebesar $4,26 \mathrm{~mm}$ dan memiliki nilai daktilitas sebesar 10,83. Dapat disimpukan bahwa terjadi kenaikan nilai daktilitas sebesar 8,67. Berikut merupakan perbandingan Grafik Gambar 9.

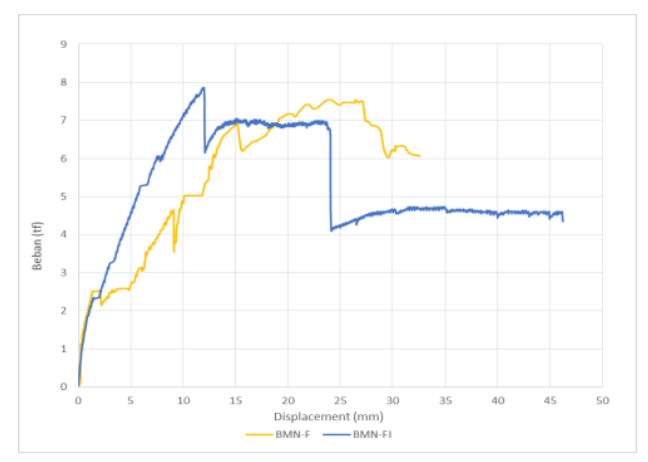

Gambar 9. Grafik Perbandingan Daktilitas

\section{Kesimpulan dan Saran}

\subsection{Kesimpulan}

Kapasitas beban siklik maksimum yang diperoleh sebesar 7,86 tf (tekan) pada kontrol beban siklus displacement $12 \mathrm{~mm}$ dan 7,37 tf (tarik) pada kontrol beban siklus displacement $12 \mathrm{~mm}$. Retak yang terjadi menyebabkan patahan pada daerah tumpuan balok. Dengan pola retak sperti ini, menandakan ferosemen cukup efektif dalam metode perbaikan struktur. Penurunan kekakuan yang diperoleh sebesar 0,109 dari displacement $0,860 \mathrm{~mm}$ sampai displacement $24,075 \mathrm{~mm}$. Energi disipasi terbesar terjadi pada kontrol beban siklus displacement $24 \mathrm{~mm}$ positif. Nilai energi disipasi terbesar sebesar 11,65 mm.tf. Nilai daktilitas yang didapatkan sebesar 10,83. Dari pembahasan dapat disimpulkan bahwa ferosemen dapat dijadikan salah satu alternatif perbaikan untuk join kolom balok yang menggunakan standar PBI 1971

\subsection{Saran}

Penelitian ini diharapkan dapat dikembangkan dan dilanjutkan mengenai perbaikan joint balok kolom standar PBI 1971 dengan menggunakan metode pelekatan ferosemen lainnya,dan juga dengan harapan bahan perbaikan dengan ferosemen ini tidak lepas lagi dari benda uji utamanya.

\section{DAFTAR PUSTAKA}

[1] BMKG, Badan Meteorologi, Klimatologi, dan Geofosika, [Online]. Available: https://www.bmkg.go.id/gempabumi/skalaintensitas-gempabumi.bmkg. [Accessed 12 Februari 2020].

[2] Badan Standarisasi Nasional, Peraturan Beton Bertulang Indonesia (PBI 1971), Jakarta: Departemen Pekerjaan Umum dan Tenaga Listrik, 1971.

[3] Kurniadi, "Keandalan Struktur Kolom Beton Bertulang pada Bangunan Gedung: studi Komparasi PBI 71 dan SNI 2847:2013", Jakarta,2020.

[4] Mulyono, Teknologi Beton, Yogyakarta: Andi, 2005.

[5] Timoshenko, Mekanika Bahan, 2nd ed., Jakarta: Erlangga, 1996.

[6] Setiawan, "Analisis Hubungan Balok Kolom Beton Bertulang Proyek Pembangunan Gedung Dprd-Balai Kota Dki Jakarta”, Jakarta, 2012.

[7] Badan Standarisasi Nasional, Standar Perencanaan Ketahanan Gempa untuk Bangunan Gedung (SNI 03-1726-2002), Bandung: Dinas Pekerjaan Umum, 2002.

[8] American Concrete Institute, Guide For The Design, Construction and Repair of Ferrocement, ACI Committee 549, Detroit, USA ,1999.

[9] Triwiyono, "Studi Eksperimental Sambungan Kolom Pondasi semi Pracetak Sistem Bataton dengan Pembebanan Aksial dan Lateral Siklik", Yogyakarta, 2011.

[10] Badan Standarisasi Nasional, SNI 2052-2017: Baja Tulangan Beton, Jakarta, 2017.

[11] American Concrete Institute, Standard Practice for Selecting Proportions for Normal, Heavyweight, and Mass Concrete, ACI Committee, USA ,1991. 